1 Holdaway MD, Turk DC. Capsulated Haemophilus influenzae and respiratory tract disease. Lancet $1967 ; \mathrm{i}: 358-60$.

2 Turk DC. The pathogenicity of Haemophilus influenzae. $f$ Med Microbiol 1984;

Reddy CM, Rao KW, Thomas FE, Anderson ER. Haemophilus parainfluenzae bacteremia with meningitis. NC Med $\mathcal{F} 1978 ; 39: 165-6$.

( CB, Golden CA, Kanner RE, Renzetti AD. Haemophilus influenzae and Haemophilus

5 Morgan AD, Rhind GB, Connaughton JJ, Calder MA. Pneumococcal serotyping and antigen detection in pneumococcal pneumonia of adults. Fournal of Infection 1984;9:134-8.

(Accepted 2 fuly 1985)

Departments of Respiratory Medicine and Bacteriology, City Hospital, Edinburgh EH10 5SB

GEORGE B RHIND, MRCP, research fellow in respiratory medicine

GRAHAME A GOULD, MRCP, research fellow in respiratory medicine

FAREEDUDDIN AHMAD, MB, MSC, registrar in bacteriology

MICHAEL J CROUGHAN, FIMLS, senior chief medical laboratory scientific officer, department of bacteriology

MARGARET A CALDER, MD, consultant bacteriologist

Correspondence to: Dr Rhind.

\section{Effect of coroners' rules on death certification for alcoholic liver disease}

In England and Wales the coroner is required by law to inquire into violent or unnatural deaths, including those resulting from poisoning. Until July 1984, when the coroners' rules were amended, chronic alcoholism was considered in this category and was a proper verdict at a coroner's inquest. patient the clinical diagnosis (sclerosing cholangitis) was found to be incorrect at necropsy (primary biliary cirrhosis) but the death certificate had not been amended.

\section{Comment}

Alcoholic liver disease is a main cause of illness and death in many industrial countries. ${ }^{12}$ Official statistics suggest that this epidemic has bypassed England and Wales, since cirrhosis is certified in only $0.3 \%$ of deaths and alcohol is implicated in under one third of these. ${ }^{2}$ Clinical experience suggests that this is a considerable underestimate. ${ }^{1}$

Inaccurate death certification has been attributed partly to the decline in frequency of postmortem examinations (now performed in under $30 \%$ of hospital deaths), ${ }^{3}{ }^{4}$ but in this study death certification in patients with alcoholic liver disease was inaccurate or incomplete despite a necropsy rate of over $90 \%$. In only one third of deaths in patients with irreversible alcoholic liver disease was this diagnosis certified. By contrast, deaths associated with non-alcoholic liver diseases were accurately recorded.

The main factor responsible for this inaccuracy appears to have been legislation (in England and Wales) requiring alcohol related deaths reported to the coroner to be the subject of a public inquest, often with distressing publicity for relatives. Our experience suggests that forensic pathologists often make a non-controversial diagnosis such as "myocardial ischaemia." In other cases clinicians omit to inform the coroner; instead a hospital necropsy is performed and the findings recorded euphemistically as "nutritional cirrhosis" or simply "cirrhosis," to avoid an inquest.

Official statistics for the United Kingdom suggest that while consumption of alcohol and deaths from cirrhosis have doubled over the past 20 years, deaths due to alcohol still account for only one third. ${ }^{2}$ If the increased mortality from cirrhosis is related to increased alcohol consumption the present proportion attributable to alcohol might be expected to be at least $50 \%$. Our findings emphasise the problems in interpreting national statistics on alcohol related mortality and consequently the difficulty in making valid international comparisons. The recent amendment of the coroners' rules to exclude

Comparison of alcoholic and non-alcoholic liver disease: mode of death, necropsy, inquest, and accuracy of death certification

\begin{tabular}{|c|c|c|c|}
\hline & Cases of alcoholic liver disease $(n=21)$ & Cases of non-alcoholic liver disease $(n=22)$ & $\begin{array}{c}\text { Statistical } \\
\text { significance } \\
\left(\chi^{2} \text { test with }\right. \\
\text { Yates's correction) }\end{array}$ \\
\hline $\begin{array}{l}\text { Men/women } \\
\text { Mean age at death (years) } \\
\text { Liver biopsy (cirrhosis) } \\
\text { Liver disease as direct cause of death }\end{array}$ & $\begin{array}{c}14 / 7 \\
60 \cdot 5 \\
20(19) \\
\text { Hepatic failure (10); variceal bleeding (5); hepatoma (2) }\end{array}$ & $\begin{array}{c}15 / 7 \\
60 \cdot 6 \\
22(10) \\
\text { Hepatoma (7); hepatic metastases (7); primary } \\
\text { biliary cirrhosis (4); chronic active hepatitis (2); } \\
\text { fulminant hepatic failure (2) }\end{array}$ & \\
\hline Other immediate cause of death & $\begin{array}{l}\text { Bronchopneumonia (1); miliary tubercle (1); } \\
\text { asphyxia/burns (1); carcinoma pancreas (1) }\end{array}$ & & \\
\hline $\begin{array}{l}\text { Necropsy } \\
\text { Forensic necropsy } \\
\text { Coroner's inquest } \\
\text { Correct liver diagnosis on death certificate } \\
\text { No mention of liver disease on certificate }\end{array}$ & $\begin{array}{r}20 / 21 \\
14 / 21 \\
7 / 21 \\
7 / 21 \\
9 / 21\end{array}$ & $\begin{array}{r}7 / 22 \\
5 / 22 \\
1 / 22 \\
18 / 22 \\
3 / 22\end{array}$ & $\begin{array}{l}p<0.001 \\
p<0.01 \\
p<0.05 \\
p<0.01 \\
p=0.07\end{array}$ \\
\hline
\end{tabular}

We were interested to examine the effect of this legislation on the accuracy of death certification in patients dying with alcoholic liver disease.

\section{Methods and results}

This retrospective study included all 43 patients who had initially presented to a general medical firm between 1976 and 1984 in whom investigations had established an unequivocal diagnosis of either alcoholic liver disease (21 cases) or non-alcoholic liver disease (22) and who were known to have subsequently died (26 at St George's Hospital, five at home, and 12 at other hospitals in south east England). Clinical diagnosis was compared with the information recorded on the death certificate.

Both routine and forensic necropsies were performed more often in patients dying with alcoholic liver disease than non-alcoholic liver disease (table). Forensic necropsy was followed by a coroner's inquest more often in patients with alcoholic liver disease. Despite the very high necropsy rate in patients with alcoholic liver disease, information on the death certificate was much more likely to be incomplete or misleading. In only seven of the 21 cases was alcoholic liver disease recorded (all the subject of a forensic necropsy and coroner's inquest), and nine had no mention of either liver disease or alcohol. In the remaining five cases various liver diagnoses were entered, including cirrhosis, micronodular cirrhosis, and nutritional cirrhosis.

By contrast, 18 of the 22 patients with non-alcoholic liver disease had a correct liver diagnosis and only three had no record of liver disease. In one deaths due to chronic alcoholism is welcome and should encourage more accurate death certification, as the necessity for an inquest has now been removed.

We are grateful for the help of Professor $M J$ Davies and the Office of Population Censuses and Surveys.

1 Saunders JB. Alcoholic liver disease in the 1980s. Br Med f 1983;287:1819-20. Morgan MY. Alcohol as a cause of liver disease in the United Kingdom. In: Hall P, ed. Alcoholic liver disease: pathology, epidemiology and clinical aspects. London:

3 Duffy GJ, Dean G. The reliability of death certification of cirrhosis. Fournal of the McGoogan E. The autopsy and clinical diagnosis. $f R$ Coll Physicians Lond
1984;18:240-3.

(Accepted 26 fune 1985)

Department of Medicine II, St George's Hospital Medical School, London SW17

J D MAXWELL, MD, FRCP, consultant physician

Westminster Coroner's Court, London SW1

PAUL KNAPMAN, MB, DMJ, barrister

Correspondence to: Dr Maxwell. 